ОБҐРУНТУВАННЯ СТРАТЕГІЧНИХ ПРІОРИТЕТІВ ДЕРЖАВНОЇ ПОЛІТИКИ РЕІНДУСТРІАЛІЗАЦІЇ ЕКОНОМІКИ УКРАЇНИ НА ЗАСАДАХ ТЕХНОЛОГІЧНОЇ МОДЕРНІЗАЦІї

\title{
THE STATE POLICY STRATEGIC PRIORITIES OF UKRAINE'S ECONOMY REINDUSTRIALIZATION ON THE BASIS OF TECHNOLOGICAL MODERNIZATION JUSTIFYING
}

УдК 330.341.1

https://doi.org/10.32843/infrastruct36-12

\author{
Шушкова Ю.В. \\ к.е.н., доцент \\ доцент кафедри державних \\ та місцевих фрінансів \\ Львівський національний університет \\ імені Івана Франка
}

\begin{abstract}
У статті обгрунтовано стратегічні пріоритети державної політики забезпечення реіндустріалізації національного господарства україни на основі технологічної модернізації базових видів економічної діяльності. Визначено стратегічну мету державної політики реіндустріалізації національного господарства України. Обгрунтовано ключові аспекти таких стратегічних пріоритетів державної політики у цій ссрері, як: створення нових виробництв у високотехнологічних галузях, зростання частки вітчизняних виробництв із застосуванням технологій п'ятого та шостого технологічних укладів, збільшення обсягів промислового виробництва в базових галузях економіки, зростання частки промислових підприємств, які впроваджують продуктові та технологічні інновації, збільшення обсягів та частки виробництва і реалізації інноваційної продукції (послуг), нарощування експорту високотехнологічної продукції, збільшення кількості інтегрованих структур.

Ключові слова: технологічна модернізація, реіндустріалізація економіки, стратегічні пріоритети, державна політика.

B cmaтье обоснованы стратегические приоритеты государственной политики
\end{abstract}

обеспечения реиндустриализации национального хозяйства Украины на основе модернизации базовых видов экономической деятельности. Определена стратегическая чель государственной поли тики реиндустриализации национального хозяйства Украины. Обоснованы ключевые аспекты таких стратегических приоритетов государственной политики в этой сорере, как: создание новых производств в высокотехнологичных отраслях, рост доли отечественных производств с применением технологий пятого и шестого технологических укладов, увеличение объемов промышленного производства в базовых отраслях экономики, рост доли промышленных предприятий, внедряющих продуктовые и технологические инновации, увеличение объемов и доли производства и реализации инновационной продукции (услуг), наращивание экспорта высокотехнологичной продукции, увеличение количества интегрированных структур.

Ключевые слова: технологическая модернизация, реиндустриализация экономики, стратегические приоритеты, государственная политика.

The article substantiates the strategic priorities of the state policy of ensuring the re-industrialization of the national economy of Ukraine on the basis of technological modernization of basic types of economic activity. The strategic goal of the state policy of reindustrialisation of the national economy of Ukraine is defined as technological modernization of existing and formation of new branches of the real sector of economy as a basis for competitiveness of the national economy. The research uses the methods of analysis and synthesis - to determine the basic methods and methodological approaches regarding the formation of a methodology for analyzing the technological modernization of Ukraine's economy, logical generalization - to identify the advantages and disadvantages, identify weaknesses and improve the methods for analyzing the technological modernization of the economy. The key aspects of such strategic priorities of state policy in this field as the creation of new industries in high-tech industries with available resource potential, the increase of the share of domestic industries with the use of technologies of the fifth and sixth technological structures, the increase of industrial production in the basic industries are substantiated new productions with technological innovations, an increase in the share of industrial enterprises introducing product and technological innovations, an increase in the volume and share of production and sales of innovative products (services), an increase in exports of high-tech products, an increase in the number of integrated structures engaged in the production and marketing of high-tech products (services) with the participation of industrial enterprises and subjects of the IT, innovation, investment and R\&D sectors. Scientific novelty of the research is to identify and substantiate the strategic priorities of the state policy of ensuring the re-industrialization of the Ukrainian economy in the system of its modernization; strategic priorities are aligned with the general purpose of state regulation, and are defined in accordance with the key conditions of modern re-industrialization. The practical significance of the results of the study is that a methodological basis for domestic state regulatory bodies has been formed. Key words: technological modernization, economic re-industrialization, strategic priorities, state policy.

Постановка проблеми. Сучасні умови глобалізації економічних відносин та загострення міжнародної конкуренції вимагають застосування нових есрективних підходів до пошуку та задіяння чинників, насамперед у галузях економіки, які забезпечують та дають змогу фрормувати конкурентні позиції національного господарства й інших галузей реального сектору економіки. Саме через масштабне технологічне переналаштування промислового комплексу на нові стандарти функціонування і розвитку країна здатна сформувати більш стабільну та стійку економіку, досягнути високого рівня самодостатності та економічної самостійності. Тут також важливо, щоб увесь комплекс прийняття та реалізації прогресивних управлінських рішень був системним, передбачуваним та узгодженим відповідно до дії норм і принципів ринкового конкурентного середовища. Відповідно, срормування векторів державної політики реіндустріалізації економіки слід планувати й у подальшому реалізовувати в рамках національних і галузевих стратегій та програм.

Аналіз останніх досліджень і публікацій. Питання узагальнення теоретико-методичних основ державної політики реіндустріалізації економіки досліджуються у працях таких науковців, як 
Т. Васильців, Р. Лупак, Т. Штець [1], С. Войтко [2], С. Касьянов [3], А. Кушнерук [4], В. Вишневський [5], Л. Піддубна [6], Ю. Кіндзерський [7], Я. Ромусік [8], П. Кузнєц [9] та ін. Водночас результати досліджень цих науковців недостатньою мірою розкривають стратегічні орієнтири державної політики забезпечення реіндустріалізації та технологічної модернізації національної економіки України.

Постановка завдання. Метою статті є обґрунтування стратегічних пріоритетів державної політики реіндустріалізації економіки України на засадах технологічної модернізації.

Виклад основного матеріалу дослідження. Стратегічне планування державної політики реіндустріалізації економіки вимагає чіткого визначення пріоритетів, за якими відбуватиметься адміністрування інноваційних процесів на мікро- та галузевому рівнях. Зокрема, стратегічні пріоритети варто розглядати як орієнтир утвердження у системі державного програмування впорядкованої структури та шляхів слідування в рамках системних передумов і дієвих механізмів для їх реалізації. Декларування складу стратегічних пріоритетів у системі державної політики реіндустріалізації національного господарства дає змогу сформувати комплексне бачення майбутніх тенденцій на ринку інновацій та технологій, необхідних супутніх рефрорм, інструментів, ув'язки інтересів інституцій різних сорер і рівнів управління в руслі політики науково-технологічного розвитку та економічного зростання на засадах інноваційно-технологічного розвитку.

Водночас у державній політиці для збереження принципів системності, виваженості, комплексності стратегічні пріоритети повинні строго підпорядковуватися її меті. Стосовно реіндустріалізації національного господарства на засадах технологічної модернізації, то мета державної політики повинна відображати не лише кінцеву ціль регулювання, а й мати проекцію на способи становлення його конкурентоспроможності, забезпечення необхідних галузево-срункціональних змін.

Однозначно, що основою реіндустріалізації мають стати інтенсивне технологічне переоснащення та модернізація, розвиток енерго- та ресурсоефективного виробництва, яке дає змогу більш повно використовувати виробничо-ресурсні потужності та матеріально-технологічну базу національного господарства як ключові чинники забезпечення конкурентоспроможності економіки.

Визначальним стратегічним пріоритетом для системи державної політики реіндустріалізації економіки $\epsilon$ збільшення обсягів промислового виробництва в базових галузях економіки за рахунок створення нових виробництв із технологічними інноваціями. Так, реальний сектор економіки вже довгий час потребує суттєвих змін, у результаті чого вдасться налагодити виробництво конкурентоспроможної продукції з високою доданою вар- тістю. Однозначно, для цього потрібне масштабне оновлення виробничих активів та активне використання прогресивних технологій. У процесі створення нових виробництв із технологічними інноваціями органам державної влади основні зусилля варто сконцентрувати на розбудові інноваційної інфраструктури, яка забезпечуватиме створення і дотримання прогресивних стандартів та технологічних регламентів у виготовленні продукції, розвиток внутрішньогалузевих зв'язків та налагодження ефрективної міжгалузевої кооперації, диверсифікації джерел ресурсного забезпечення активної інноваційної діяльності та ін.

Органам державного управління потрібно брати активнішу участь у збільшенні частки промислових підприємств, які впроваджують продуктові та технологічні інновації. Тут стратегічно важливо, щоб підприємства отримували належну публічно-приватну підтримку під час залучення фрінансово-інвестиційних ресурсів, у т.ч. зовнішніх, промоції перспективних техніко-технологічних проектів, закупівлі високотехнологічних імпортних технологій, комерціалізації та захисту інтелектуальної власності. А це потребує фрормування належного інституціонального середовища, у якому підприємства здатні будуть активно налагоджувати співробітництво 3 науково-дослідними та навчальними організаціями, фрінансово-кредитними, страховими та іншими інституціями допоміжної інфраструктури інвестиційно-інноваційної діяльності, брати участь у підготовці та реалізації фрінансово-інвестиційних програм, збільшувати масштаби державно-приватного партнерства в інвестиційній та інноваційній сферах, реалізовувати перспективні фрорми і проєкти інноваційнотехнологічної діяльності.

У міру реалізації стратегічних пріоритетів реіндустріалізації економіки на засадах технологічної модернізації повинна сорормуватися така сукупність умов, які забезпечуватимуть стабільність фрінансово-інвестиційного забезпечення високотехнологічної діяльності, нагромадження виробничого інноваційно-технологічного потенціалу, високий рівень якості інституційно-правового регулювання науково-дослідної та проектно-конструкторської роботи. Так, для створення нових виробництв у високотехнологічних галузях із наявним ресурсним потенціалом повинна бути ссрормована високоякісна система професійної підготовки та збільшуватися кількість кваліфрікованих спеціалізованих кадрів. Відповідно, підприємства зможуть розраховувати на кращі професійно-кваліфікаційні характеристики працівників та їхню здатність до генерування нововведень, зростання еорективності і продуктивності праці. Як свідчить світовий досвід, залежність від висококваліфрікованої праці постійно посилюється, а у високотехнологічних галузях особливо явно це виражається. Тут роль 
державної влади полягає у задіянні механізмів, які поліпшують забезпечення розвитку галузі освіти та науки, стандарти та форми освіти, посилюють інтеграцію вітчизняної та світової науки.

Необхідною умовою для побудови нових виробничих інноваційно-технологічних об'єктів є забезпечення високого рівня захищеності та комерціалізації об'єктів права інтелектуальної власності і раціоналізаторських пропозицій. Так, у нашій країні повинно бути забезпечене фрункціонування інститутів ринку інтелектуальної власності, розроблення та реалізація механізмів фрормування й ефективного використання інтелектуального капіталу і попередження його еміграції, стимулювання попиту на результати вітчизняних наукових досліджень і розробок, імплементування норм міжнародного законодавства у цій сфрері.

Усе більше трансформація світового ринку зумовлена науково-технологічним прогресом, формуванням нових технологічних укладів. Як уже зазначалося, в Україні застосування технологій п'ятого та шостого технологічних укладів відбувається досить повільно, а для поліпшення ситуації необхідна активна державна підтримка влади. Утім, для збільшення частки вітчизняних виробництв із застосуванням найвищих технологічних укладів повинна бути сорормована мережа елементів дієздатної інфраструктури науководослідної та інноваційно-технологічної діяльності.

В Україні вже довгий час існує необхідність створення ринкових інституцій для забезпечення інвестиційної підтримки виробництва продукції вищої технологічної складності. Одними з таких об'єктів є інвестиційні майданчики, створення яких дає змогу краще задовольняти фрінансові інтереси виробників високотехнологічної продукції, поліпшити організаційно-технічне забезпечення інноваційної діяльності. Основною метою таких майданчиків повинно стати поліпшення середовища доступу підприємств базових видів економічної діяльності до джерел фрінансово-ресурсного забезпечення. Також такі майданчики виконуватимуть фрункції пошуку та розроблення, опрацювання перспективних інвестиційно-інноваційних проектів, інформаційно-аналітичного забезпечення в підтримці нових високотехнологічних виробництв.

Одним із важливих аспектів реалізації інвестиційних проектів у реальному секторі економіки $€$ налагодження міжфункціональних і міжгалузевих коопераційних відносин, розвиток яких особливо важливий в інноваційно-технологічній сорері. Це дає змогу забезпечити нарощування та створення замкнутих циклів виробництва високоякісної продукції, залучати в більших обсягах інноваційні розробки та технології, оптимізувати джерела сировинно-ресурсного забезпечення. Завдяки коопераційному підходу суб'єкти реального сектору економіки здатні краще реалізувати науково-технологічний та виробничий потенціал, поглибити співробітництво з науково-дослідними та проектно-конструкторськими установами.

Окрім ресурсного забезпечення для промислових підприємств, які впроваджують продуктові та технологічні інновації, важливо безперешкодно проходити дозвільно-погоджувальні процедури. Так, від державних органів влади вимагається сприяти мінімізації трансакційних витрат під час відкриття виробничих об'єктів, проходження патентування та сертиорікації продукції, отримання інших погоджувальних документів (експертних висновків, довідок, паспортів). Також важливо, щоб під час проходження дозвільно-погоджувальних процедур зберігалися техніко-технологічна комерційна таємниця, бізнес-імідж тощо.

У державній політиці реіндустріалізації на засадах технологічної модернізації в контексті забезпечення збільшення обсягів та частки виробництва і реалізації інноваційної продукції (послуг) варто передбачити низку умов, що визначатимуть ступінь виконання такого важливого стратегічного завдання, зокрема: стимулювання попиту на інноваційну продукцію вітчизняного виробництва; посилення зорієнтованості мережі об'єктів торгівлі на продаж інноваційних товарів вітчизняного виробництва; розширення системи державних закупівель високотехнологічної продукції вітчизняного виробництва; поліпшення кон'юнктури ринку інновацій і технологій.

Однозначно, що за недостатнього попиту забезпечувати нарощування виробничих потужностей та постійне зростання обсягів реалізації інноваційної продукції об'єктивно складно. Отже, у країні повинні відбуватися зміни, які стимулюватимуть достатній рівень попиту на вітчизняну інноваційну продукцію. Йдеться про, по-перше, зростання доходів населення; по-друге, про утвердження споживчої культури населення відносно споживчих переваг на користь вітчизняних продуктових інновацій; по-третє, про формування стандартів якості та ціноутворення на високотехнологічну продукцію; по-четверте, про розвиток торговельно-посередницької сорери передачі передових технологій. Усе це має стати предметами державної програми, у якій буде чітко визначатися перелік, обсяги фрінансування, часові межі і масштаби реалізації стимулюючих заходів, а також відповідальні органи на різних рівнях державного управління.

Державні реформи у сорері інноваційно-технологічної модернізації економіки України повинні стосуватися також розбудови мережі об'єктів торгівлі, орієнтованих на продаж інноваційних товарів вітчизняного виробництва. Тут від органів державної влади вимагається таке: надавати на пільгових умовах земельні ділянки під будівництво торговельних об'єктів чи приміщень, де в асортименті переважаючою буде частка високоякісних товарів 
вітчизняного виробництва; організовувати фрінансово-інвестиційну допомогу (пільгове оподаткування, відтермінування бюджетних платежів, безвідсоткове кредитування чи часткова компенсація відсотків за кредитами) торговельним підприємствам у разі відкриття магазинів із товарним асортиментом виключно вітчизняного виробництва; спростити процедури офрормлення прав та організації процесів проектування торгових будівель, що спеціалізуватимуться на продажу вітчизняної високотехнологічної продукції; гарантувати бюджетне фрінансування (субсидування) під час відкриття магазинів на малоекономічно розвинених територіях для продажу товарів, в асортименті яких переважатимуть вітчизняні розробки з характеристиками інноваційності.

Технологічна модернізація в Україні відбувається в умовах високої імпортозалежності економіки, зокрема ресурсне забезпечення промислового виробництва щонайменше на половину забезпечується імпортом, що посилює залежність і створює загрози економічній безпеці держави. Тож пріоритетне значення має збільшення у структурі держзамовлень частки продукції вітчизняного виробництва, особливо високотехнологічного походження, навіть якщо вона й поступається іноземним аналогам за ціновими критеріями. Масштабні державні замовлення 3 відповідною орієнтацією можуть активно стимулювати залучення іноземних інвестицій із подальшим створенням спільних підприємств чи відкриттям власних виробництв на території нашої країни.

Також у державній політиці реіндустріалізації на засадах технологічної модернізації необхідно передбачити заходи щодо забезпечення розвитку внутрішнього ринку інновацій і високих технологій. Однозначно, що відсутність такого ринку суттєво перешкоджає налагодженню виробництва високоякісної продукції. Тут роль державних органів влади має проявлятися у забезпеченні інтеграції науково-дослідної та виробничо-технологічної діяльності, зміцненні зв'язків між учасниками науково-інноваційного процесу, розвитку інноваційної інфрраструктури.

Попри збільшення обсягів реалізації високотехнологічної продукції на внутрішньому ринку, велике значення має розширення масштабів її експорту. Для цього в країні повинні фрункціонувати експортно-консалтингові агентства просування на зовнішні ринки продукції вітчизняного виробництва. Згідно зі світовою практикою, агентства виконують фрункції: збільшення масштабів міжнародного науково-технологічного та виробничого співробітництва; удосконалення маркетингово-логістичних транскордонних схем постачання товарів в об'єкти торгівлі на зовнішніх ринках; посилення маркетингово-промоційної підтримки позицій вітчизняних виробників за кордоном; реалізація інвестиційних проектів зі створення торговельно-логістичних центрів розвитку міжнародної торгівлі.

Окрім того, українські експортери високотехнологічної продукції повинні активніше впроваджувати міжнародні стандарти якості та безпечності. Це дасть змогу посилити якість і конкурентоспроможність вітчизняних товарів, інвестиційну привабливість виробничо-експортних комплексів, співробітництво з іноземними партнерами, брати участь у міжнародних виставках та ярмарках, поліпшити диференціацію фрорм і способів збуту й просування інноваційних товарів за кордоном. Окрім того, це позитивно вплине на внутрішнє конкурентне середовище, в якому вітчизняна високотехнологічна продукція не поступатиметься за якістю, безпечністю та іншими характеристиками імпорту й здатна буде його витісняти.

Безперечно, одним з основних критеріїв налагодження та розвитку високотехнологічного експортоорієнтованого виробництва $€$ фрормування міцних міжнародних науково-технологічних і виробничо-інвестиційних зв'язків, за рахунок яких експортер має кращий доступ до фрінансовокредитної підтримки, ширші можливості для впровадження інновацій та результатів НДДКР, участі у міжнародних інтегрованих промислово-виробничих та збутових кластерах.

Усе більшого значення для налагодження виробництва і збуту високотехнологічної продукції (послуг) мають інтеграційні кластерні зв'язки, які поєднують економічні інтереси суб'єктів різних видів економічної діяльності (інорормаційнотехнологічної, інноваційної, інвестиційної, науково-дослідної та дослідно-конструкторської). А це вимагає від державної системи влади нормативно-методичної, інформаційно-аналітичної, інституційно-організаційної та іншої підтримки. Світовий досвід підтверджує значні переваги кластерної моделі, адже вона дає змогу успішно реалізувати всі стадії технологічної модернізації (від дослідно-виробничої до комерціалізації та виведення на ринок продуктивних інновацій), забезпечити зростання інноваційної активності суб'єктів базових видів економічної діяльності, підвищити якість потенціалу виробництва високотехнологічної та конкурентоспроможної продукції.

Іншою вимогою до збільшення кількості інтегрованих структур у сорері технологічних інновацій та виробництва $€$ розширення масштабів державно-приватного партнерства. Таким чином, пріоритетне значення у контексті реіндустріалізації економіки України на засадах технологічної модернізації мають створення нових об'єктів виробництва високотехнологічної продукції, застосування у промисловості інновацій вищих технологічних укладів, створення і збільшення обсягів діяльності інтегрованих виробничо-торговельних та науково-технологічних систем (рис. 1). 


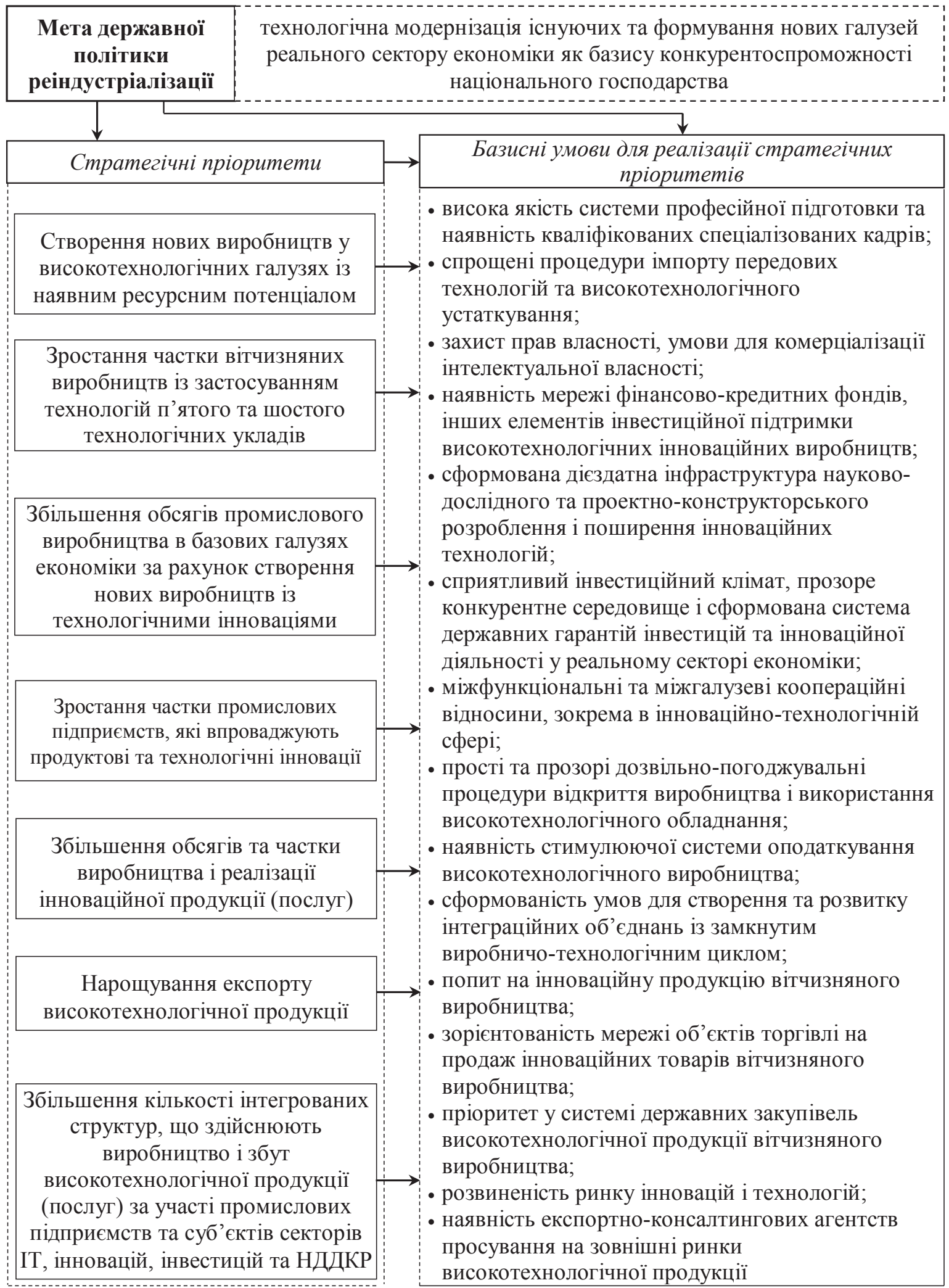

Рис. 1. Стратегічні пріоритети реіндустріалізації економіки України на засадах технологічної модернізації

У державній політиці реіндустріалізації на засадах технологічної модернізації сорормованість базових умов для реалізації стратегічних пріоритетів визначається рівнем ефективності проведених інституціональних та структурних реформ. Так, у контексті інституціонального блоку в країні повинні відбутися зміни стосовно вдосконалення нормативно-правової та інституційно-організаційної бази здійснення і збільшення обсягів інноваційно-технологічної діяльності, розвитку просторово-видової 
мережі інфрраструктури (інвестиційно-інноваційних, страхових, фрінансово-кредитних, венчурних, гарантійних фрондів), створення вертикально інтегрованих структур із виробництва високоякісної конкурентоспроможної високотехнологічної продукції.

щодо структурних зрушень, то вони повинні стосуватися аспектів фрормування та підвищення ефективності використання інноваційно-технологічного потенціалу, поліпшення фрінансово-інвестиційного, матеріально-технічного та іншого ресурсного забезпечення розвитку високотехнологічного виробництва.

Відповідно, для ефективної реалізації державної політики реіндустріалізації у країні повинно утвердитися якісне регуляторне та бізнес-середовище, яке сприятиме розвитку підприємницького інноваційного потенціалу у розробленні та реалізації проектів і програм, спрямованих на створення сучасних конкурентоспроможних технікотехнологічних виробничих комплексів.

Висновки з проведеного дослідження. Стратегічною метою державної політики реіндустріалізації економіки України є технологічна модернізація існуючих та фрормування нових галузей реального сектору економіки як базису конкурентоспроможності національного господарства. При цьому реалізація державної політики реіндустріалізації вітчизняної економіки на засадах технологічної модернізації забезпечується сорормованістю базових умов та їх узгодженням зі стратегічними пріоритетами реіндустріалізації. 3 огляду на це, стратегічні пріоритети державної політики реіндустріалізації стосуються: створення нових виробництв у високотехнологічних галузях із наявним ресурсним потенціалом; зростання частки вітчизняних виробництв із застосуванням технологій п'ятого та шостого технологічних укладів; збільшення обсягів промислового виробництва в базових галузях економіки за рахунок створення нових виробництв 3 технологічними інноваціями; зростання частки промислових підприємств, які впроваджують продуктові та технологічні інновації; збільшення обсягів та частки виробництва і реалізації інноваційної продукції (послуг); нарощування експорту високотехнологічної продукції; збільшення кількості інтегрованих структур, що здійснюють виробництво і збут високотехнологічної продукції (послуг) за участі промислових підприємств та суб'єктів секторів IT, інновацій, інвестицій та НДДКР.

\section{БІБЛІОГРАФІЧНИЙ СПИСОК:}

1. Васильців Т.Г., Лупак Р.Л., Штець Т.Ф. Обґрунтування стратегічних напрямів, цілей та заходів державної політики реалізації потенціалу IT-сектору економіки України. Підприємництво і торгівля. 2018. Вип. 23. С. 56-63.

2. Войтко С.В. Управління розвитком наукомістких виробництв : монографрія. Київ : ВПІ Політехніка, 2012. 280 c.
3. Касьянов С. Державна допомога виробникам в Україні: ресрормування відповідно до норм СОТ та ЄС. Київ : Нора-друк, 2004. 86 с.

4. Кушнерук А.С. Досвід реалізації державної промислової політики в західних розвинених країнах. Актуальні проблеми економіки. 2012. № 6(132). C. 54-61.

5. Національна модель неоіндустріального розвитку України : монографрія / за заг. ред. В.П. Вишневського. Київ : НАН України, Ін-т економіки промисловості, 2016. 519 с.

6. Піддубна Л.І. Конкурентоспроможність економічних систем : монографрія. Київ : ІНЖЕК, 2007. 367 c.

7. Кіндзерський Ю.В. Промисловість України: стратегія та політика структурно-технологічної модернізації : монограсрія. Київ : Ін-т економіки та прогнозування НАН України, 2013. 536 с.

8. Ромусік Я.В. Технологічна структура економіки: вітчизняні та світові тенденції. Ефрективна економіка. 2013. № 11. С. 1-5.

9. Kusnets P.W. An East Asian Model of Economic Development: Japan, Taiwan, and South Korea. Ecnomic Development and cultural Change. 1988. № 36. P. 11-43.

10. Vasyltsiv T.G., Lupak R.L., Osadchuck Yu.M. Assessement of the level of penetration of import dependence in the context of the import substitution policy in Ukraine. Економічний часописXXI. 2017. № 167(9-10). P. 13-17.

\section{REFERENCES:}

1. Vasyltsiv T.G., Lupak R.L., Shtets' T.F. (2018) Obgruntuvannya stratehichnykh napryamiv, tsiley ta zakhodiv derzhavnoyi polityky realizatsiyi potentsialu ITsektoru ekonomiky Ukrayiny [Substantiation of strategic directions, goals and measures of the state policy of realizing the potential of the IT sector of the Ukrainian economy]. Entrepreneurship and trade, vol. 23, pp. 56-63.

2. Voytko V.S. (2012) Upravlinnia rozvytkom naukomistkyh vyrobnytstv [Management of the development of high-tech industries]. Kyiv : VPI Politehnika. (in Ukrainian)

3. Kas'yanov S. (2004) Derzhavna dopomoga vyrobnykam v Ukrayini: reformuvannia vidpovidno do norm SOT I YeS [State aid to producers in Ukraine: WTO and EU reform]. Kyiv : Nora-druk. (in Ukrainian)

4. Kushneruk A.S. (2012) Dosvid realizaciyi derzhavnoyi promyslovoyi polityky $v$ zahidnuh rozvynenyh krayinah [Experience in implementing state industrial policy in the western developed countries]. Current economic problems. no. 6 (132), pp. 54-61.

5. Vyshnens'kyi V.P. (2016) Nacional'na model' neoindustrial'nogo rozvytku Ukrainy [National model of neo-industrial development of Ukraine]. Kyiv : Instytut ekonomiky promyslovosti NAN Ukrainy. (in Ukrainian)

6. Piddubna L.I. (2007) Konkurentosporomozhnist' ekonomichnyh system [Competitiveness of economic systems]. Kyiv : Inzhek. (in Ukrainian)

7. Kindzerskyi Yu.V. (2013) Promyslovist' Ukrainy: strategiya ta polityka strukturno-tehnologichnoyi modernizaciyi [Industry of Ukraine: strategy and policy of structural and technological modernization]. Kyiv : Instytut ekonomiky promyslovosti NAN Ukrainy. (in Ukrainian) 
8. Romusik Ya.V. (2013) Tehnologichna struktura ekonomiky: vitchyzniani ta svitovi tendenciyi [Technological structure of the economy: domestic and world trends]. An efficient economy. no. 11, pp. 1-5.

9. Kusnets P.W. (1988) An East Asian Model of Economic Development: Japan, Taiwan, and South Korea.
Ecnomic Development and cultural Change. № 36. pp. 11-43.

10. Vasyltsiv T.G., Lupak R.L., Osadchuck Yu.M. (2017) Assessement of the level of penetration of import dependence in the context of the import substitution policy in Ukraine. Economic Journal-XXI, no. 167 (9-10), pp. 13-17.

\section{Shyshkova Yulia \\ Candidate of Economic Sciences, Associate Professor, Senior Lecturer at Department of State and Local Finance Ivan Franko National University of Lviv}

\section{THE STATE POLICY STRATEGIC PRIORITIES OF UKRAINE'S ECONOMY REINDUSTRIALIZATION ON THE BASIS OF TECHNOLOGICAL MODERNIZATION JUSTIFYING}

Purpose of the article. The purpose of the article is to substantiate the strategic priorities of the state policy of re-industrialization of the Ukrainian economy on the basis of technological modernization. The article substantiates the strategic priorities of the state policy of ensuring the re-industrialization of the national economy of Ukraine on the basis of technological modernization of basic types of economic activity. The strategic goal of the state policy of reindustrialisation of the national economy of Ukraine is defined as technological modernization of existing and formation of new branches of the real sector of economy as a basis for competitiveness of the national economy.

Research Methodology. The research uses the methods of analysis and synthesis - to determine the basic methods and methodological approaches regarding the formation of a methodology for analyzing the technological modernization of Ukraine's economy, logical generalization - to identify the advantages and disadvantages, identify weaknesses and improve the methods for analyzing the technological modernization of the economy.

Results. The key aspects of such strategic priorities of state policy in this field as the creation of new industries in high-tech industries with available resource potential, the increase of the share of domestic industries with the use of technologies of the fifth and sixth technological structures, the increase of industrial production in the basic industries are substantiated new productions with technological innovations, an increase in the share of industrial enterprises introducing product and technological innovations, an increase in the volume and share of production and sales of innovative products (services), an increase in exports of high-tech products, an increase in the number of integrated structures engaged in the production and marketing of high-tech products (services) with the participation of industrial enterprises and subjects of the IT, innovation, investment and R\&D sectors. It is established that the implementation of the state policy of re-industrialization of the domestic economy on the basis of technological modernization is ensured by the formation of the following conditions: creation of new industries in high-tech industries; growth of the share of domestic industries with the use of technologies of the fifth and sixth technological structures; increase in industrial production in basic sectors of the economy; the growth of the share of industrial enterprises introducing product and technological innovations, etc.

Novelty. Scientific novelty of the research is to identify and substantiate the strategic priorities of the state policy of ensuring the re-industrialization of the Ukrainian economy in the system of its modernization; strategic priorities are aligned with the general purpose of state regulation, and are defined in accordance with the key conditions of modern re-industrialization.

The practical significance. The practical significance of the results of the study is that a methodological basis for domestic state regulatory bodies has been formed. 